From

\title{
THE PROCEEDINGS OF THE ROYAL ENTOMOLOGICAL SOCIETY OF LONDON
}

Series A. GENERAL ENTOMOLOGY

Vol. 14, Parts 2-3, March 15th, 1939

The Royal Entomological Society of London, 41, Queen's Gate, S.W.7

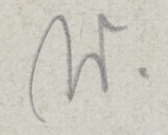


rcin.org.pl 
By Sir Edward PouLton, F.R.S.

A Box containing the female parent of the form lamborni (prototrophonius), the pupae of five of her offspring and the letter of 4 July 1938, written by my friend Canon Rogers and quoted below, was delivered at Oxford by air-mail and reached our house on 12 July or perhaps on the following day.

$$
\text { " Ngong P.O., Nairobi. }
$$

"I am sending you in a small box five pupae of $P$. dardanus together with the female parent. I only had 9 pupae and one of them damaged itself in pupating and, as they did not feed up very regularly, the others are too early to send. I thought perhaps you might be interested to see the butterfly alive to which you have given so much of your time, and now that the mails go home so quickly there is some chance that they will reach you before they emerge. They sometimes remain in the pupal stage as little as 16 days but generally a few days longer and occasionally hang over for several weeks.

"I have recently sent home five families of $P$. dardanus to the B.M. and in case Mr. Ford may be interested I send particulars of the of offspring on a separate sheet."

The female parent was labelled "Langata, Nairobi, 4.5.38." Concerning this locality my friend wrote :-

"Langata is the name I use for an extensive area of forest where I do much of my collecting. It is some five miles west of Nairobi and the elevation is about $5700 \mathrm{ft}$."

The pupae were taken to the Hope Department on 14 July and Prof. Hale Carpenter at once removed them to a warmer atmosphere in his house. On the morning of 21 July he found that the first butterfly, a hippocoonides o , had appeared and, as the wings were expanded and dry, emergence had probably taken place in the night or during the previous day when he was away from Oxford. The date of emergence was remarkably tactful, for the Entomological Club was meeting with Dr. Eltringham at Stroud on 21 July and the company had the great pleasure of watching the dignified movements of the first living imago of this classical species to be seen in England.

The five pupae produced the following female forms, all of which, with their pupal shells and the female parent, were exhibited to the meeting :-

1 hippocoonides emerged 20-21 July 1938.

2 hippocoonides emerged 4 or 5 August 1938.

1 lamborni (prototrophonius) emerged 7 August 1938.

1 hippocoonides emerged 14 August 1938.

To these must be added 2 lamborni and 2 males produced by the pupae retained by Canon Rogers, as recorded in his letter of 1 Oct., quoted below :-

"The pupae I retained emerged as follows:-

$$
\begin{gathered}
\text { July } 18-\hat{0} . \\
,, \quad 22-\hat{0} \text {. } \\
,, \quad 29-0 \text { lamborni. }
\end{gathered}
$$

Sept. 12-o lamborni.

PROC. R. ENT. SOC. LOND. (A) 14. PTS. 2-3. (MAR. 1939.) 
"The lamborni of July 29 was from the damaged pupa and was a little crippled but able to fly though rather weakly.

"I have another small brood slowly emerging from a hippocoonides 우 which so far has produced 3 hippocoonides and 4 protosalaami."

My friend Mr. E. B. Ford writes on these last-mentioned results :-

"It has already been shown ${ }^{1}$ that there are good grounds for believing that the difference between hippocoonides and protosalaami is unifactorial, and that the latter behaves as a simple dominant. The male parent therefore appears to have been a heterozygote and the female a homozygous recessive. This would lead to segregation in equality which, approximately, is attained. It may, however, be observed that the numbers are too small to separate this from other possible ratios, were one to rely on the evidence which is at present available from this family. It resembles No. 90 in the above-mentioned paper, in which a protosalaami female produced 13 offspring, 6 being protosalaami and 7 hippocoonides, but differs in that the genetic constitution of the parents is reversed relative to their sex.

"In the family first described a female of the prototrophonius (lamborni) form produced 3 prototrophonius and 4 hippocoonides females. It is known that the difference between true trophonius and hippocoonides is unifactorial but it is not known which of them is dominant. There is evidence, furthermore, to show that trophonius and its more primitive stage prototrophonius are genetic modifications of the same gene, though this is not entirely conclusive. The present family suggests segregation in equality, on which basis one may presume one parent to be heterozygous and the other the homozygous recessive. It is indeed similar to No. 88 (Ford, loc. cit.) in which a prototrophonius female produced 6 prototrophonius and 5 hippocoonides. Thus these two families, while not inconsistent with previous deductions, throw no new light upon the genetics of prototrophonius."

In sending these notes Mr. Ford also wrote that a much smaller amount of work than that already devoted to the breeding of dardanus from captured females, "would have been sufficient to establish all the simpler aspects of the genetics of the species had it been conducted in accord with genetic requirements along the lines suggested for future research in my paper." These words bring home to us the fruitful results which may be hoped for by the method of transport which Canon Rogers has so successfully demonstrateda method which may be confidently expected to bring an inexhaustible store of liying and healthy material within the reach of our laboratories at home.

FRESHLY EMERGED AGLAIS URTICAE (LINN.), CAPTURED BY BIRDS WHILE OLDER SPECIMENS WERE NEGLECTED: A WHINCHAT PHOTOGRAPHED HOLDING A CAPTURED HESPERID BUTTERFLY

\section{By Sir Edward Poulton, F.R.S.}

Mr friend Mr. C. J. Grist wrote to me, 4 July 1938, describing an interesting difference in the behaviour of birds towards released butterflies-a difference which, I think, was more probably caused by a recognition of greater alertness

1 Ford, E. B. (1936), Trans. R. ent. Soc. Lond. 85 : 435-66. For the names protosalaami and prototrophonius (lamborni) see p. 442.

PROC. R. ENT. SOC. LOND. (A) 14. PTS. 2-3. (MAR. 1939.) 
rcin.org.pl 
rcin.org.pl 